\title{
Prescribing for polymyalgia rheumatica
}

\section{David F Liew \\ Rheumatologist and Clinical pharmacology fellow \\ Claire E Owen \\ Rheumatologist \\ Russell R Buchanan \\ Director of Rheumatology \\ Austin Health \\ Melbourne}

\section{Keywords}

corticosteroids, giant cell arteritis, methotrexate, polymyalgia rheumatica, prednisolone

Aust Prescr 2018;41:14-9 https://doi.org/10.18773/ austprescr.2018.001

\section{SUMMARY}

Polymyalgia rheumatica is a common inflammatory condition but can be difficult to diagnose. Treatment is warranted in all cases to manage disabling symptoms.

Low-moderate doses of oral corticosteroids are highly effective. Once symptoms improve they can often be gradually reduced over months, but most patients require either prolonged or continuous treatment.

Despite their effectiveness, corticosteroids cause disproportionate damage in polymyalgia rheumatica compared to other rheumatic diseases. The therapeutic aim is to prescribe the minimum possible dose required for symptom control.

There is a lack of definitive evidence for steroid-sparing drugs in polymyalgia rheumatica. Methotrexate is typically used for relapsing disease. Leflunomide and tocilizumab are being investigated, but further research is needed.

\section{Introduction}

Polymyalgia rheumatica is the second most common autoimmune rheumatic disease after rheumatoid arthritis, with a lifetime risk of $2.4 \%$ for women, and $1.7 \%$ for men. It is the most common rheumatic disease in patients over 50 years old.'

Polymyalgia rheumatica and its treatment are often poorly understood by patients and healthcare professionals alike. The diagnosis can be difficult and there is a frequent dependence on corticosteroid therapy despite an increased propensity for long-term adverse effects.

\section{Clinical features}

The onset of polymyalgia rheumatica can be abrupt, often seemingly occurring overnight. There is bilateral shoulder girdle pain and prolonged early morning stiffness (typically $>45$ minutes, but often lasting several hours). The hips are involved in the vast majority of patients, ${ }^{2}$ with neck, back or buttock pain also commonly reported. Distal manifestations are less frequent and may include a peripheral arthritis of the wrists and knees which is typically more sensitive than rheumatoid arthritis to prednisolone. ${ }^{3}$

It is possible to confuse polymyalgia rheumatica with other conditions including rheumatoid arthritis, spondyloarthritis, mechanical tendinopathies and fibromyalgia. To further complicate matters, elderly-onset rheumatoid arthritis may have an initial 'polymyalgic' presentation before overt arthritis emerges.

\section{Diagnosis}

The difficulty with diagnosis is accentuated by the absence of a gold standard investigation. Patients typically have a raised erythrocyte sedimentation rate or C-reactive protein, but infrequently the inflammatory markers are normal. Although interleukin- 6 is typically elevated in untreated patients, no specific biomarker exists. Alternative diagnoses such as myositis, infection, malignancy and endocrinopathies should be excluded (Box). ${ }^{2,4}$

$A$ rapid resolution of symptoms in response to prednisolone $15 \mathrm{mg}$ daily was previously thought to represent a diagnostic surrogate for polymyalgia rheumatica. However, a small proportion of patients do not respond to three weeks of this therapy ${ }^{5}$ so it cannot be used to make the diagnosis. Classification criteria therefore combine clinical features and serology with the optional incorporation of ultrasound (Table 1). ${ }^{6}$ Ultrasound may show bursitis or tenosynovitis. In practice, the diagnosis is a clinical one and may require specialist involvement.

\section{Giant cell arteritis}

The most feared complication of polymyalgia rheumatica is giant cell arteritis. These conditions are closely related, and $16-21 \%$ of patients with polymyalgia rheumatica either have or will go on to develop giant cell arteritis. ${ }^{7}$ All patients with polymyalgia rheumatica should be educated about this complication and the need to seek urgent medical attention if they develop suggestive symptoms. Giant cell arteritis may present with 
headache, localised scalp tenderness, jaw claudication and, more concerningly, sudden visual loss or stroke. A small rise in erythrocyte sedimentation rate does not exclude giant cell arteritis. ${ }^{7}$ Giant cell arteritis requires high-dose corticosteroids, which should never be delayed while a diagnostic temporal artery biopsy is obtained.

Extracranial giant cell arteritis is under-recognised and most commonly presents with constitutional features and persistently elevated inflammatory markers. Untreated it can eventually lead to formation of aortic aneurysms or stenoses of other large arteries. ${ }^{8}$ Imaging is being increasingly used to detect extracranial giant cell arteritis. CT angiography or magnetic resonance angiography may be useful. Nuclear medicine studies such as positron emission tomography (PET) with fluorodeoxyglucose (FDG) have been used. ${ }^{9}$ Although cost and radiation limit its use in routine practice, PET can identify important differential diagnoses such as infection and malignancy, and characteristic features of polymyalgia rheumatica may also be seen. ${ }^{10}$

\section{Corticosteroids}

Typically, untreated disease is markedly disabling due to the combination of pain, extensive stiffness and accompanying constitutional features. Corticosteroid therapy is therefore indicated and can result in a dramatic improvement for many patients. However, there is no evidence to suggest that it alters the likelihood of developing giant cell arteritis.

Prednisolone $15 \mathrm{mg}$ daily is highly effective in most patients, although a few may need up to $25 \mathrm{mg}$ daily. ${ }^{11-13}$ Moderate-dose corticosteroids have been the first-line treatment for over 50 years, but were introduced before the widespread use of placebocontrolled trials to confirm effectiveness. ${ }^{12}$

After several weeks of treatment, approximately onethird of patients are able to gradually reduce their prednisolone over many months and can eventually stop. ${ }^{14}$ Different weaning protocols have been devised, although the ideal approach remains controversial and individual tailoring may be necessary.

The British Society of Rheumatology has proposed a regimen ${ }^{15}$ which is globally accepted ${ }^{2}$ and reflected in local guidelines. ${ }^{16}$ This recommends prednisolone $15 \mathrm{mg}$ daily for three weeks, then tapering to $12.5 \mathrm{mg}$ daily for an additional three weeks, $10 \mathrm{mg}$ daily for 4- 6 weeks and then a reduction of $1 \mathrm{mg}$ daily every 4-8 weeks thereafter. Disease relapse, defined by a recurrence of symptoms accompanied by a rise in inflammatory markers, warrants an escalation of prednisolone to the last effective dose before recommencing the weaning schedule from that dose.
Box Important differential diagnoses of polymyalgia rheumatica

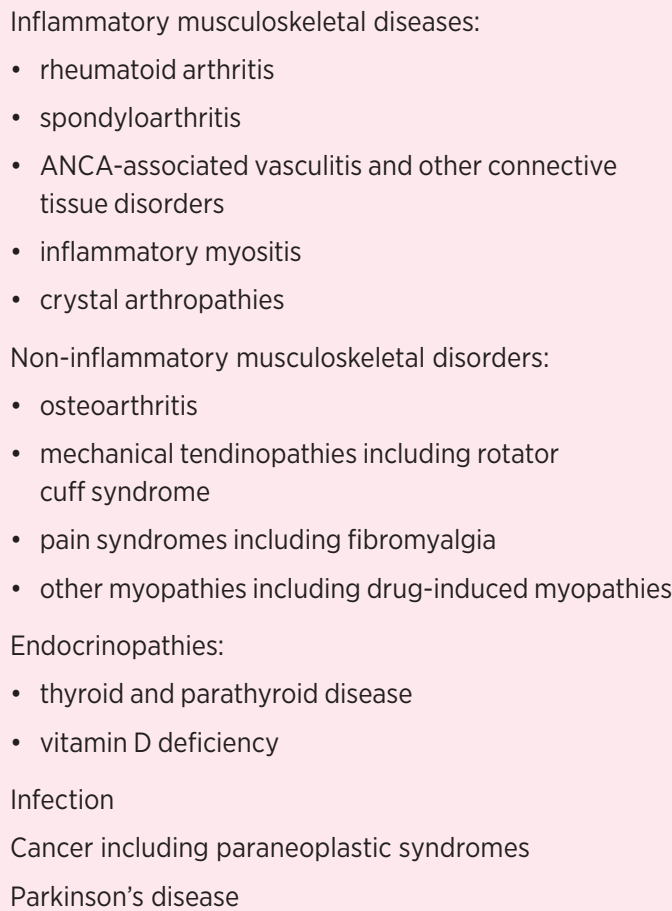

Inflammatory musculoskeletal diseases:

- rheumatoid arthritis

- spondyloarthritis

- ANCA-associated vasculitis and other connective tissue disorders

- inflammatory myositis

- crystal arthropathies

Non-inflammatory musculoskeletal disorders:

- osteoarthritis

- mechanical tendinopathies including rotator cuff syndrome

- pain syndromes including fibromyalgia

- other myopathies including drug-induced myopathies

Endocrinopathies:

- thyroid and parathyroid disease

- vitamin D deficiency

Infection

Cancer including paraneoplastic syndromes

Parkinson's disease

ANCA antineutrophil cytoplasmic antibody

\section{Table 1 Scoring algorithm for classifying polymyalgia rheumatica}

Required criteria: age $\mathbf{5 0}$ years or older, bilateral shoulder aching and abnorma C-reactive protein or erythrocyte sedimentation rate

\begin{tabular}{lll} 
Criteria & $\begin{array}{l}\text { Points without } \\
\text { ultrasound } \\
(\mathbf{0}-\mathbf{6})\end{array}$ & $\begin{array}{l}\text { Points with } \\
\text { ultrasound } \\
\mathbf{( 0 - 8 )}\end{array}$ \\
\hline Morning stiffness duration $>45$ min & 2 & 2 \\
\hline Hip pain or limited range of motion & 1 & 1 \\
$\begin{array}{l}\text { Absence of rheumatoid factor or anticitrullinated } \\
\text { protein antibody }\end{array}$ & 2 & 2 \\
\hline $\begin{array}{l}\text { Absence of other joint involvement } \\
\begin{array}{l}\text { At least one shoulder with subdeltoid bursitis, or } \\
\text { biceps tenosynovitis, or glenohumeral synovitis } \\
\text { (either posterior or axillary), and at least one hip }\end{array}\end{array}$ & Not applicable & 1 \\
$\begin{array}{l}\text { with synovitis or trochanteric bursitis } \\
\begin{array}{l}\text { Both shoulders with subdeltoid bursitis, biceps } \\
\text { tenosynovitis or glenohumeral synovitis }\end{array}\end{array}$ & Not applicable & 1 \\
\hline
\end{tabular}

* A patient is categorised as having polymyalgia rheumatica if the total score without ultrasound is 4 points, or is 5 or more points with ultrasound.

Source: Reference 6 
The British weaning schedule is more rapid than most others, but involves at least 46 weeks of prednisolone therapy. This is a much longer period of exposure compared to most other inflammatory diseases. In practice the majority of patients will need corticosteroids for at least two years and a large proportion will require ongoing low-dose prednisolone to control their symptoms. ${ }^{17}$ There are currently few data to help predict which patients will require ongoing therapy. Extended exposure to prednisolone is inevitable for these patients.

\section{Adverse effects}

Corticosteroids cause dose-dependent adverse effects. While the doses of prednisolone used in polymyalgia rheumatica might be lower than what was historically considered acceptable in many inflammatory conditions, they still confer a burden of morbidity.

The damage from prolonged use of low-moderate doses of corticosteroids is multimodal and has been better appreciated in recent years with more sophisticated investigative methods (Table 2)..$^{18-20}$ Screening for these complications and treating them is important in mitigating their impact, although prevention is preferable.

In polymyalgia rheumatica the morbidity from similar doses of corticosteroids is both greater and occurs more frequently than in other rheumatic diseases. ${ }^{21}$ It is not clear why, and this area warrants further research as it may have therapeutic implications. The cumulative effect, however, is that up to $81 \%$ of patients develop adverse events in the first year. ${ }^{5}$ Furthermore polymyalgia rheumatica is a disease of older people who are at risk of complications as a consequence of these adverse events.

Uncontrolled inflammation itself can also cause problems, therefore corticosteroid therapy in polymyalgia rheumatica is a balance. Aim to achieve the minimum total exposure to prednisolone while maintaining control of the disease. ${ }^{4}$

\section{Steroid-sparing drugs}

There is great impetus to develop treatment alternatives to corticosteroids. However, there is currently no alternative drug in polymyalgia rheumatica which is supported by good evidence and is affordable. Steroid-sparing drugs, such as methotrexate, are therefore not currently recommended to be started soon after diagnosis, as is the case in rheumatoid arthritis. The decision to commence a steroid-sparing drug is a personalised one based on perceived ongoing need for prednisolone. It is not possible to predict who will benefit. One approach is to consider a steroid- sparing drug in patients who flare at least twice while following the British weaning schedule $e^{15}$ or who develop overt inflammatory arthritis.

Methotrexate is currently recommended by both international ${ }^{4}$ and local guidelines ${ }^{16}$ as the first-line steroid-sparing drug to consider in polymyalgia rheumatica. These recommendations acknowledge that the evidence to support this advice is of poor quality. Leflunomide might have promise, ${ }^{22,23}$ and it is currently the subject of a trial in Europe, but there may be problems with individualising the dosing. ${ }^{24}$ Both of these drugs are used in rheumatoid arthritis, but there is no role for most other antirheumatic drugs in polymyalgia rheumatica. ${ }^{4}$ This emphasises the fact that polymyalgia rheumatica is not merely an extension of rheumatoid arthritis. The use of either leflunomide or methotrexate in polymyalgia rheumatica is off label so specialist oversight is recommended.

Tocilizumab, an interleukin- 6 receptor antagonist, has become of increasing interest as interleukin- 6 is elevated in polymyalgia rheumatica. ${ }^{25}$ The drug has also had recent success in treating giant cell arteritis, ${ }^{26}$ but there are important immunological differences between the two diseases ${ }^{27}$ so the results are not necessarily transferrable. Dedicated studies in polymyalgia rheumatica are therefore required. Two phase II trials have supported the use of tocilizumab ${ }^{28,29}$ and a phase III trial is currently underway. ${ }^{30}$ Even if this trial is successful, the cost of tocilizumab is likely to be prohibitive for routine use, and there is a risk of serious infection, myelosuppression, hypertension and dyslipidaemia. ${ }^{31}$

\section{Conclusion}

Polymyalgia rheumatica can be hard to diagnose and to treat optimally. While corticosteroids are effective and necessary to prevent disease-related morbidity, they have a burden of morbidity themselves and no steroid-sparing drug has yet emerged as ideal for routine use. Close clinical monitoring is important to detect the evolution of giant cell arteritis and to minimise and manage the adverse effects of therapy.

More research is required into the mechanisms behind corticosteroid-related damage in polymyalgia rheumatica. There is also a need to find ways to predict which patients are likely to require prolonged corticosteroids, and to devise a pragmatic therapeutic approach for them. $<$

David Liew attended Editorial Executive Committee meetings as the clinical pharmacology registrar for Australian Prescriber in 2017. He is supported by the Ronald John Gleghorn Bursary through the University of Melbourne. 


\section{Table 2 Long-term toxicity of prednisolone ( $\leq 15$ mg daily)}

\begin{tabular}{lll}
\hline Toxicity & Details & Implications for screening and management* \\
\hline Musculoskeletal & & \\
\hline Osteoporosis & $\begin{array}{l}\text { Reduced bone density } \\
\text { Increased fracture risk }\end{array}$ & $\begin{array}{l}\text { Optimise vitamin D and calcium intake } \\
\text { Consider DEXA screening }\end{array}$ \\
& Possible increased risk & $\begin{array}{l}\text { Order plain-film X-rays for new back pain } \\
\text { Consider bisphosphonates or denosumab }\end{array}$ \\
\hline Osteonecrosis & $\begin{array}{l}\text { Risk of painless proximal muscle } \\
\text { weakness and atrophy }{ }^{+}\end{array}$ & $\begin{array}{l}\text { Take history, including difficulty with activities } \\
\text { above shoulder height or rising from chairs } \\
\text { Myopathy }\end{array}$ \\
\hline
\end{tabular}

\section{Metabolic}

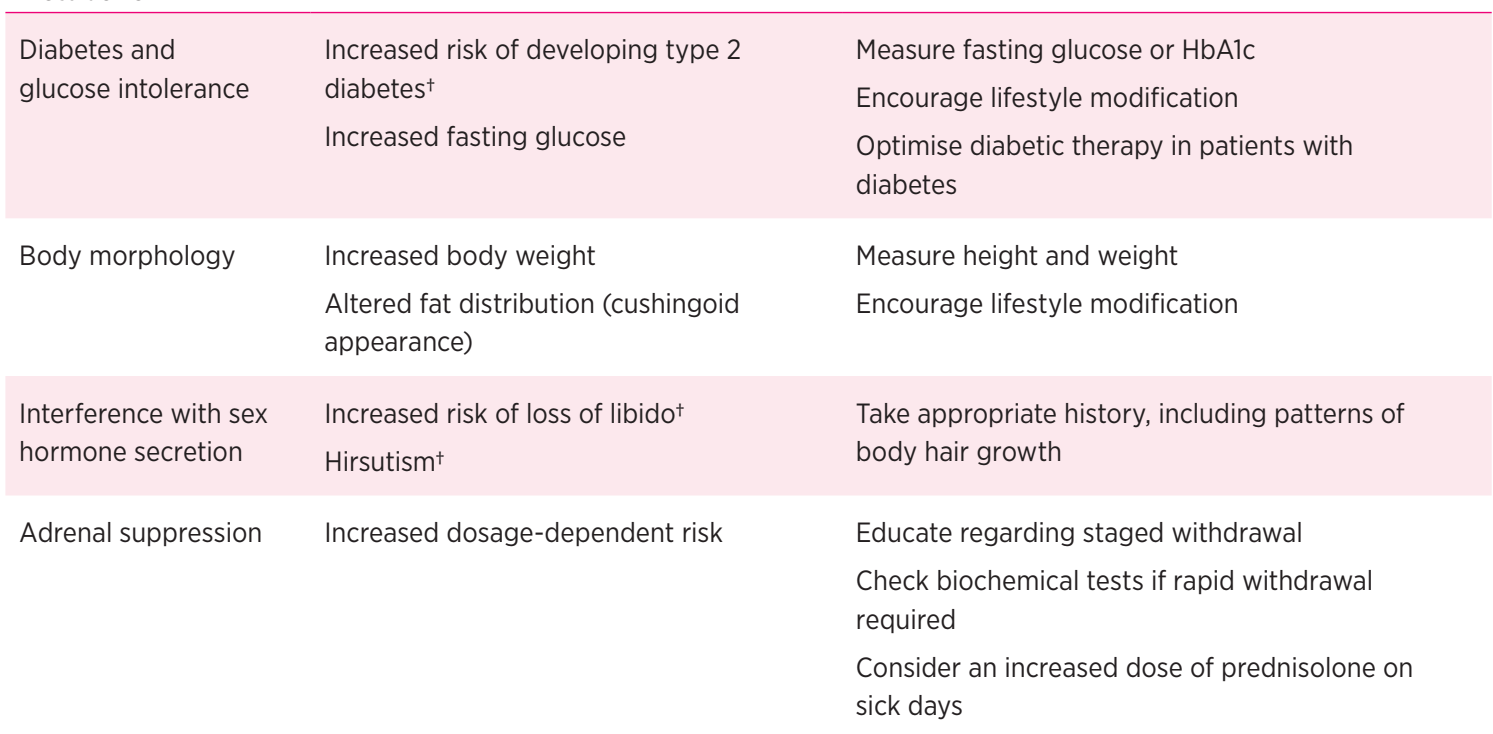

\section{Cardiovascular}

Dyslipidaemia

Increased dyslipidaemia

Measure fasting lipids ${ }^{\dagger}$

Encourage lifestyle modification and provide pharmacotherapy

Hypertension

Increased blood pressure ${ }^{\dagger}$

Monitor blood pressure ${ }^{\dagger}$

Encourage lifestyle modification and pharmacotherapy

Atherosclerosis and

Increased risk of cardiovascular events

Encourage lifestyle modification ischaemic heart and subclinical atherosclerosis ${ }^{\dagger}$

disease

Possible increased risk of

cardiovascular events

\section{Infections}

\begin{tabular}{lll}
\hline $\begin{array}{l}\text { Infections } \\
\text { Possible increased risk of general } \\
\text { infection } \\
\text { Possible increased risk of opportunistic } \\
\text { infection and herpes zoster }\end{array}$ & $\begin{array}{l}\text { Give scheduled vaccinations (inactivated) } \\
\text { including influenza vaccination }\end{array}$ \\
\hline Dermatological & Educate regarding late presentation of symptoms \\
\hline $\begin{array}{l}\text { Skin atrophy } \\
\text { Acne, alopecia, }\end{array}$ & Increased risk & Educate \\
\hline
\end{tabular}




\section{Table 2 Long-term toxicity of prednisolone ( $\leq 15 \mathrm{mg}$ daily) (continued)}

\begin{tabular}{|c|c|c|}
\hline Toxicity & Details & Implications for screening and management* \\
\hline \multicolumn{3}{|l|}{ Ophthalmological } \\
\hline Cataract & Increased risk & Consider ophthalmologic evaluation if symptomatic \\
\hline Glaucoma & $\begin{array}{l}\text { Increased risk in individuals already } \\
\text { at risk }{ }^{\dagger}\end{array}$ & $\begin{array}{l}\text { Consider ophthalmologic evaluation with } \\
\text { tonometry in at-risk patients }\end{array}$ \\
\hline \multicolumn{3}{|l|}{ Psychological } \\
\hline $\begin{array}{l}\text { Mood disturbance } \\
\text { and psychosis }\end{array}$ & Increased risk ${ }^{\dagger}$ & $\begin{array}{l}\text { Educate, screen and provide therapy } \\
\text { as appropriate }\end{array}$ \\
\hline Insomnia & Increased risk & Educate, take dose in morning \\
\hline \multicolumn{3}{|l|}{ Gastrointestinal } \\
\hline Peptic ulcer disease & Possible increased risk & $\begin{array}{l}\text { Consider proton pump inhibitor only in patients } \\
\text { at risk of ulcers }\end{array}$ \\
\hline \multicolumn{3}{|c|}{$\begin{array}{l}\text { * Management of all of these adverse events includes minimisation of the corticosteroid dose. } \\
+ \text { Applies to moderate doses (prednisolone } \geq 7.5 \mathrm{mg} \text { daily) only, based on References 18-20. } \\
\text { DEXA dual-energy x-ray absorptiometry } \\
\text { HbA1c glycated haemoglobin }\end{array}$} \\
\hline
\end{tabular}

\section{REFERENCES}

1. Crowson CS, Matteson EL, Myasoedova E, Michet CJ, Ernste FC, Warrington KJ, et al. The lifetime risk of adult-onset rheumatoid arthritis and other inflammatory autoimmune rheumatic diseases. Arthritis Rheum 2011;63:633-9. https://doi.org/10.1002/art.30155

2. Kermani TA, Warrington KJ. Polymyalgia rheumatica. Lancet 2013;381:63-72. https://doi.org/10.1016/S0140-6736(12)60680-1

3. Cutolo M, Cimmino MA, Sulli A. Polymyalgia rheumatica vs late-onset rheumatoid arthritis. Rheumatology (Oxford) 2009;48:93-5. https://doi.org/10.1093/rheumatology/ken294

4. Dejaco C, Singh YP, Perel P, Hutchings A, Camellino D, Mackie S, et al.; European League Against Rheumatism American College of Rheumatology. 2015 Recommendations for the management of polymyalgia rheumatica: a European League Against Rheumatism/American College of Rheumatology collaborative initiative. Ann Rheum Dis 2015;74:1799-807. https://doi.org/10.1136/ annrheumdis-2015-207492

5. Hutchings A, Hollywood J, Lamping DL, Pease CT, Chakravarty K, Silverman B, et al. Clinical outcomes, quality of life, and diagnostic uncertainty in the first year of polymyalgia rheumatica. Arthritis Rheum 2007:57:803-9. https://doi.org/10.1002/art.22777

6. Dasgupta B, Cimmino MA, Maradit-Kremers H, Schmidt WA Schirmer M, Salvarani C, et al. 2012 provisional classification criteria for polymyalgia rheumatica: a European League Against Rheumatism/American College of Rheumatology collaborative initiative. Ann Rheum Dis 2012;71:484-92. https://doi.org/10.1136/annrheumdis-2011-200329

7. Salvarani C, Cantini F, Hunder GG. Polymyalgia rheumatica and giant-cell arteritis. Lancet 2008:372:234-45. https://doi.org/10.1016/S0140-6736(08)61077-6

8. Weyand CM, Goronzy JJ. Clinical practice. Giant-cell arteritis and polymyalgia rheumatica. N Engl J Med 2014;371:50-7. https://doi.org/10.1056/NEJMcp1214825

9. Buttgereit F, Dejaco C, Matteson EL, Dasgupta B. Polymyalgia rheumatica and giant cell arteritis: a systematic review. JAMA 2016;315:2442-58. https://doi.org/10.1001/jama.2016.5444

10. Sondag M, Guillot X, Verhoeven F, Blagosklonov O, Prati C, Boulahdour $\mathrm{H}$, et al. Utility of 18F-fluoro-dexoxyglucose positron emission tomography for the diagnosis of polymyalgia rheumatica: a controlled study. Rheumatology (Oxford) 2016;55:1452-7. https://doi.org/10.1093/rheumatology/kew202
11. Hernández-Rodríguez J, Cid MC, López-Soto A, Espigol-Frigolé G, Bosch X. Treatment of polymyalgia rheumatica: a systematic review. Arch Intern Med 2009:169:1839-50. https://doi.org/10.1001/ archinternmed.2009.352

12. Yates M, Watts RA, Swords F, MacGregor AJ. Glucocorticoid withdrawal in polymyalgia rheumatica: the theory versus the practice. Clin Exp Rheumatol 2017;35:1-2.

13. Owen CE, Buchanan RR, Hoi A. Recent advances in polymyalgia rheumatica. Intern Med J 2015;45:1102-8. https://doi.org/10.1111/imj.12823

14. Weyand CM, Fulbright JW, Evans JM, Hunder GG, Goronzy JJ. Corticosteroid requirements in polymyalgia rheumatica. Arch Intern Med 1999;159:577-84. https://doi.org/10.1001/ archinte.159.6.577

15. Dasgupta B, Borg FA, Hassan N, Barraclough K, Bourke B, Fulcher J, et al.; BSR and BHPR Standards, Guidelines and Audit Working Group. BSR and BHPR guidelines for the management of polymyalgia rheumatica. Rheumatology (Oxford) 2010;49:186-90. https://doi.org/10.1093/ rheumatology/kep303a

16. Rheumatology 3 Expert Group. Therapeutic Guidelines: rheumatology. Version 3. Melbourne: Therapeutic Guidelines Limited: 2017. www.tg.org.au [cited 2018 Jan 1]

17. Kremers HM, Reinalda MS, Crowson CS, Zinsmeister AR, Hunder GG, Gabriel SE. Relapse in a population based cohort of patients with polymyalgia rheumatica. J Rheumatol 2005:32:65-73.

18. Da Silva JA, Jacobs JW, Kirwan JR, Boers M, Saag KG, Inês LB, et al. Safety of low dose glucocorticoid treatment in rheumatoid arthritis: published evidence and prospective trial data. Ann Rheum Dis 2006;65:285-93. https://doi.org/ 10.1136/ard.2005.038638

19. Strehl C, van der Goes MC, Bijlsma JW, Jacobs JW, Buttgereit F Glucocorticoid-targeted therapies for the treatment of rheumatoid arthritis. Expert Opin Investig Drugs 2017:26:187-95. https://doi.org/10.1080/13543784.2017.1276562

20. van der Goes MC, Jacobs JW, Boers M, Andrews T, Blom-Bakkers MA, Buttgereit F, et al. Monitoring adverse events of low-dose glucocorticoid therapy: EULAR recommendations for clinical trials and daily practice. Ann Rheum Dis 2010;69:1913-9. https://doi.org/10.1136/ ard.2009.124958 
21. Hoes JN, Jacobs JW, Verstappen SM, Bijlsma JW, Van der Heijden GJ. Adverse events of low- to mediumdose oral glucocorticoids in inflammatory diseases: a meta-analysis. Ann Rheum Dis 2009;68:1833-8. https://doi.org/10.1136/ard.2008.100008

22. Adizie T, Christidis D, Dharmapaliah C, Borg F, Dasgupta B. Efficacy and tolerability of leflunomide in difficult-to-treat polymyalgia rheumatica and giant cell arteritis: a case series. Int J Clin Pract 2012;66:906-9. https://doi.org/10.1111/ j.1742-1241.2012.02981.x

23. Diamantopoulos AP, Hetland $H$, Myklebust G. Leflunomide as a corticosteroid-sparing agent in giant cell arteritis and polymyalgia rheumatica: a case series. Biomed Res Int 2013;2013:120638. https://doi.org/10.1155/2013/120638

24. Hopkins AM, O'Doherty CE, Foster DJ, Upton RN, Proudman SM, Wiese MD. Individualization of leflunomide dosing in rheumatoid arthritis patients. Per Med 2014;11:449-61. https://doi.org/10.2217/pme.14.23

25. Alvarez-Rodríguez L, Lopez-Hoyos M, Mata C, Marin MJ, Calvo-Alen J, Blanco R, et al. Circulating cytokines in active polymyalgia rheumatica. Ann Rheum Dis 2010;69:263-9. https://doi.org/10.1136/ard.2008.103663

26. Stone JH, Tuckwell K, Dimonaco S, Klearman M, Aringer M, Blockmans $D$, et al. Trial of tocilizumab in giant-cell arteritis. N Engl J Med 2017;377:317-28. https://doi.org/10.1056/ NEJMoa1613849
27. Weyand CM, Hicok KC, Hunder GG, Goronzy JJ. Tissue cytokine patterns in patients with polymyalgia rheumatica and giant cell arteritis. Ann Intern Med 1994;121:484-91. https://doi.org/10.7326/0003-4819-121-7-199410010-00003

28. Devauchelle-Pensec V, Berthelot JM, Cornec D, Renaudineau Y, Marhadour T, Jousse-Joulin S, et al. Efficacy of first-line tocilizumab therapy in early polymyalgia rheumatica: a prospective longitudinal study. Ann Rheum Dis 2016;75:1506-10. https://doi.org/10.1136/ annrheumdis-2015-208742

29. Lally L, Forbess L, Hatzis C, Spiera R. Brief Report: A prospective open-label phase lla trial of tocilizumab in the treatment of polymyalgia rheumatica. Arthritis Rheumato 2016;68:2550-4. https://doi.org/10.1002/art.39740

30. ClinicalTrials.gov. [Internet]. Bethesda (MD): National Library of Medicine (US). 2000 Feb 3. Identifier NCT02908217, Safety and efficacy of tocilizumab versus placebo in polymyalgia rheumatica with glucocorticoid dependence (SEMAPHORE); 2016 Sep 16. https://clinicaltrials.gov/ct2/ show/NCT02908217 [cited 2018 Jan 1]

31. Wilsdon TD, Hill CL. Managing the drug treatment of rheumatoid arthritis. Aust Prescr 2017:40:51-8. https://doi.org/10.18773/austprescr.2017.012 